\title{
EFFECT OF VARMAM THERAPY IN SANTHU VATHAM (OSTEO ARTHRITIS-KNEE JOINT)-A SINGLE CASE STUDY
}

\author{
MEENA R. ${ }^{* 1}$, NATARAJAN S. ${ }^{2}$, ANBARASI C. ${ }^{3}$, MURALIDASS SD ${ }^{4}$ \\ 1,2,3Research Officer (Siddha), Varmam, Thokkanam and Traditional Bone Setting Division, Department of Clinical Research, Siddha \\ Central Research Institute, Chennai, India, ${ }^{4}$ Siddha Central Research Institute, Chennai, India \\ Email: meenaprakashphd@gmail.com
}

Received: 04 Jun 2017 Revised and Accepted: 22 Jul 2017

\begin{abstract}
Santhu vatham is a vatha disease mentioned in the Siddha text book Yugi vaidhya chindhamani. The clinical features can be equated to osteo arthritis of knee joint. Varmam therapy is one of the external therapies mentioned in Siddha literature. A 68 y old male from chennai reported to the varmam, narambiyal matrum enbumurivu OPD of Siddha Central Research Institute (SCRI) on 2.5.2015 with chief complaints of pain and swelling in both knee joints since $5 \mathrm{y}$. He was given varmam therapy. Varma points are points where the pranan, ie, vital energy of our body is concentrated (residing). The treatment is given for $45 \mathrm{~d}$ for once in $2 \mathrm{~d}$ for $15 \mathrm{~min}$. The pain was assessed using visual analogue score before and after treatment. The pain was markedly reduced after treatment. The range of movements of the knee joint was also improved.
\end{abstract}

Keywords: Azhal keel vayu, Siddha, Varmam, Osteo arthritis, Case study, Pain

(C) 2017 The Authors. Published by Innovare Academic Sciences Pvt Ltd. This is an open access article under the CC BY license (http://creativecommons.org/licenses/by/4.0/) DOI: http://dx.doi.org/10.22159/ijpps.2017v9i9.20487

\section{INTRODUCTION}

Santhu vatham is one of the 80 vatha diseases mentioned by sage Yugi in his textbook Yugi vaithiya cindhamani [1]. Santhu vatham of the Knee joint can be equated to primary osteoarthritis is a common disorder of the elderly and patients are often asymptomatic. Approximately $80-90 \%$ of the individuals older than 65 y have the evidence of primary osteoarthritis [2].

Approximately, 4\% of the world's current population is affected by osteoarthritis. In India, osteoarthritis is the second most prevalent disease after diabetes [3]. It is the most frequent joint disease with a prevalence of 22-39\% in India. Women are also more prone to erosive osteoarthritis, with a female-to-male ratio of about 12:1. Though pharmacological, mechanical and surgical interventions are used in modern medicine, there is no known cure for osteoarthritis at present. Nowadays the only management for osteoarthritis is pain management by NSAIDS. The side effects of intake of NSAID for prolonged period are well known. So, in the present global scenario, there is a need for a cost-effective remedy without side effects. Siddha system of medicine has effective external therapies for pain management. Varmam is one such external manipulation technique which challenges the requirements.

Varmam is an ancient South Indian divine martial art. Later it evolved as a therapy. It was introduced by Siddhars, the ancient scientists. The human body has 108 varmam points. The varma points are divided into divided into two main divisions and two sub divisions: the main divisions are padu varmam (12 points) and thodu varmam (96 points) [4]; Kannan Rajaram in 2010 has mentioned the sub divisions of varmam as uzh varmam (6 points) and thattu varmam (8 points). Varma points are points where the pranan, ie, vital energy of our body is concentrated (residing). They have a wide range of therapeutic applications. It encompasses different manipulation techniques. The basic objective of the varmam therapy is to stimulate these points to cure diseases. When one or many varmam points are manipulated therapeutically, they produce curative effects in many diseased conditions. In order to give a safe and effective treatment using varmam therapy, this single case study has been carried out.

\section{CASE REPORT}

A 68 y old male from Chennai, who is a retired bus conductor reported to the varmam, narambiyal matrum enbumurivu OPD of Siddha
Central Research Institute on 2.5.2015 with chief complaints of pain and swelling in both knee joints since $5 \mathrm{y}$. The pain increases on floor level activities, walking for more than a kilometre, stair case activities.

He was mentally stressed due to chronic intermittent pain. There was limited participation in family activities and difficulty in taking care of young grandchildren.

\section{Medical history}

He was previously treated with NSAIDs for 6 mo with frequent intervals (from May 2014 to November 2014).

He is using corticosteroid inhalers daily.

\section{Socio economic status}

He hails from a middle-income group and is residing in Chennai, Tamilnadu.

Marital status: Married.

\section{Personal history}

He takes the mixed diet. He is of normal built. He is a non-smoker, non-alcoholic.

\section{Co-morbid conditions}

He is a non-diabetic, nonhypertensive, non-hyperlipidemic. He is a known asthmatic since $30 \mathrm{y}$. There is no history of trauma, seizures, pulmonary tuberculosis, ischemic heart diseases etc.

\section{Muscle power}

As per MCR grading, the muscle power was assessed in both lower limbs. Quadriceps and hamstrings muscle power was $4 / 5$ in both lower limbs.

\section{Diagnostic focus}

Routine laboratory investigations were within normal limits. The provisional diagnosis was made as osteoarthritis of both knee joints using the following criteria. The American College of Rhematological classification criteria for osteoarthritis of the knee includes radiographic evidence for osteophytes and at least one of the following three items: 
- $\quad$ Age $\geq 50 y r s$

- Morning stiffness $\leq 30 \mathrm{~min}$ in duration

- Crepitus on motion
The clinical examination and x-ray of both knee joints confirmed the diagnosis as osteo arthritis of both knee joints. As per the Kellgren and Lawrence grading system for radiographic evidence, the present case falls under grade 2 (definite osteophytes, definite narrowing of joint space).

General examination

\begin{tabular}{ll}
\hline Pulse rate & $76 / \mathrm{min}$. \\
Heart rate & $76 / \mathrm{min}$ \\
Respiratory rate & $18 / \mathrm{min}$ \\
Blood pressure & $130 / 80 \mathrm{~mm} \mathrm{Hg}$ \\
Pallor & No \\
Jaundice & No \\
Cyanosis & No \\
Lymphadenopathy & No \\
Pedal edema & No \\
Clubbing & No \\
Jugular venous pulsation & Not visible \\
\hline
\end{tabular}

\section{Physical examination}

Gait: Normal.

Table 1: Assesment of both knee joints before treatment

\begin{tabular}{lll}
\hline Signs & Right knee joint & Left knee joint \\
\hline Tenderness & & Positive \\
Medial joint line & Positive & Positive \\
Lateral joint line & Positive & Coarse crepitations in both active and passive means \\
Crepitations & Coarse crepitations in both active and passive means & $37.5 \mathrm{~cm}$ \\
Swelling & $38.5 \mathrm{~cm}$ & No warmth \\
Warmth & Present & 140 \\
Range of movements & & 0 \\
Flexion & 120 & Nil \\
Extension & 0 & Present \\
Deformities & Nil & Nil \\
Morning stiffness & Present & Nil \\
Joint stability & & $1 \mathrm{~km}$ \\
Antero posterior instability & Present & No noticeable muscle wasting \\
Mediolateral instability & Nil & \\
Walking distance without pain & $1 / 2 \mathrm{~km}$ & No noticeable muscle wasting \\
Muscle atropy & &
\end{tabular}

\section{Assessment}

Pain intensity was assessed by VAS pain score. The score before treatment was 6/10.

The pain score and the degree of range of movements were assessed on every visit.

Intervention: varmam therapy.

\section{Therapeutic focus}

Varmam therapy is given to the patient once in $2 \mathrm{~d}$. The varmam points applied were given below:

Kaal mootu varmam, panchamuga varmam, komberi varmam, kaal sanni adangal (kaal kavuli kalam), ullankaal vellai varmam, and Kutri varmam.

Location of varmam points and the manipulation technique $[5,6]$

\section{Kaal mootu varmam}

Location: centre of the popliteal fossa.

Technique: tips of the middle three fingers were placed over the mootu varmam. The point was pressed three times. (in pumping motion).

\section{Panchamuga varmam}

Location: around the patella.
Technique: the tips of thumbs were placed along the upper border of the patella and glided over the borders and stopped at the lower border of the patella.

\section{Komberi kalam}

Location: eight finger breadths above the medial malleolus.

Technique: the tips of the middle three fingers were placed over the komberi kalam and was pressed three times (in a pumping motion) towards the medial border of the patella.

\section{Kaal sanni adangal}

Location: at the junction of big and second toe.

Technique: pressure was given by pressing and releasing the tip of the index finger placed over the varmam point.

\section{Ullankaal vellai varmam}

Location: at the junction of big toe and second toe in the plantar region. Technique: pressure was given by pressing and releasing the thumb placed over the varmam point

\section{Kutri varmam}

Location: tragus of the ear.

Technique: the tragus was moved in antero posterior direction using thumb and index finger. 
Pressure given: half mathirai.

Treatment duration: 15 min for each sitting.

Treatment period: $45 \mathrm{~d}$. (varmam treatment was given once in $2 \mathrm{~d}$ ).

Posture: Sitting posture.

The following advice was given to patients, avoid climbing stairs, avoid sour taste food, avoid tubers, avoid chill foods etc. The patient was cautioned to avoid high-impact activities like running and jumping.

\section{Follow-up}

After $45 \mathrm{~d}$, the patient was followed for 1 mo for any recurrence. Pinda thylam was prescribed during the follow-up period.

\section{Outcome}

The outcome assessment after treatment is given in the table 2 .

\section{DISCUSSION}

In this present case study a $68 \mathrm{y}$ old male with symptoms of pain and swelling in both knee joints since $5 \mathrm{y}$. The pain increases on floor level activities, walking for more than a kilometer, stair case activities. He responded well to varmam treatment. The pain score by VAS was $6 / 10$ before treatment. The swelling in right knee joint was $38.5 \mathrm{~cm}$. The swlling reduced to $37 \mathrm{~cm}$ after treatment. The pain score has come down to $3 / 10$ after varmam treatment. The patient was able to walk around $2.5 \mathrm{~km}$ without pain in rt. leg and $3 \mathrm{~km}$ without pain in left leg. The crepitation in left knee was reduced. The joint line tenderness also reduced after treatment. The pressure manipulation with these varmam points would have interacted with the mechanism of the pain pathway. The varmam therapy may trigger a somatic autonomic reflex. Varmam may also challenge the levels of neurotransmitters such as serotonin and dopamine, thereby affecting the emotional stress. By affecting the pain modulating neuro transmittors such as endorphin and encephalin, the pain is relieved. The analgesic effect beta endorphins is produced by binding to opioid receptors at both pre-and postsynaptic nerve terminals. They primarily exert their effect through pre synaptic binding. A cascade of interactions results in inhibition of the release of tachykinins, a key protein involved in the transmission of pain after binding to opioid receptors [7-9].

Also, the application of pinda thylam during the follow-up period reduces the crepitations in the knee joints and provide lubrication to the knee joints. The present treatment for osteo arthritis is the use of NSAIDs, which give temporary relief. The partial osteotomy, knee replacements which may result in blood clot development, Urinary infections etc. immediately after replacement the patient may experience stiffness of knee joints. A replaced knee can never be as good as the natural one. So, to maintain a good quality of life the external therapies like varmam therapy render helping hands to patients.

Table 2: Assessment of both knee joints after treatment

\begin{tabular}{|c|c|c|}
\hline Signs & Right knee joint & Left knee joint \\
\hline \multicolumn{3}{|l|}{ Tenderness } \\
\hline Medial joint line & Negative & Negative \\
\hline Lateral joint line & Negative & Negative \\
\hline Crepitations & Coarse crepitations in both active and passive means & Nil \\
\hline Swelling & $37 \mathrm{~cm}$ & $37.5 \mathrm{~cm}$ \\
\hline Warmth & No warmth & No warmth \\
\hline \multicolumn{3}{|l|}{ Range of movements } \\
\hline Flexion & 140 & 140 \\
\hline Extension & 0 & 0 \\
\hline Deformities & Nil & Nil \\
\hline Morning stiffness & Reduced & Reduced \\
\hline \multicolumn{3}{|l|}{ Joint stability } \\
\hline Antero posterior instability & Reduced & Nil \\
\hline Mediolateral instability & Nil & Nil \\
\hline Walking distance without pain & $2.5 \mathrm{~km}$ & $3 \mathrm{~km}$ \\
\hline Muscle atropy & No noticeable muscle wasting & No noticeable muscle wasting \\
\hline
\end{tabular}

VAS Pain score: 3/10.

\section{Informed consent}

A written informed consent is obtained from the patient before the start of the treatment.

\section{CONCLUSION}

Osteo arthritis is the major cause for knee replacement. The analgesics and anti-inflammatory drugs cannot be administered on a long run. It is found that varmam treatment is helpful for patients who no longer respond to NSAIDs and in those for whom NSAIDs are contraindicated. So far no adverse reactions were reported with varmam treatment. So this external therapy would be a better alternative. Intervention with varmam therapy in early stages of osteoarthritis may prevent the development of deformities and surgical intervention.

\section{ACKNOWLEDGEMENT}

The authors sincerely thank the Dr. P. Sathiyarajeswaran, Assistant Director, Scientist II, Incharge of Siddha Central Research Institute and the Prof. Dr. R. S. Ramaswamy, Director General, Central Council for Research in Siddha, Chennai for their support.

\section{AUTHORS CONTRIBUTION}

R. Meena-followed the case, gave varmam therapy, wrote the case study.

S. Natarajan-taught the varmam points.

C. Anbarasi-helped in structuring the paper.

SD Muralidass---took a detailed history of the patient.

\section{CONFLICT OF INTERESTS}

\section{Declared none}

\section{REFERENCES}

1. Siddha Maruthuvam Podhu, Kuppusamy Mudhaliyar. Department of Indian Medicine and Homoeopathy, Chennai. 7 thed; 2007. p. 590.

2. Roberts J, Burch TA. Osteoarthritis prevalence in adults by age, sex, race, and geographic area. Vital Health Stat 1966;11:1-27.

3. Survey Titled, TNS AROGYA 2006-07. The Health Monitor conducted by TNS, an ISO-accredited market research agency in Delhi; 2007. 
4. R Thiyagarajan, Anaivaari R Anandhan. Special medicines in Siddha. Department of Indian Medicine and Homoeopathy, Chennai. $1^{\text {st }}$ ed; 2009. p. 114.

5. Traditional and complementary medicine practice guideline on Varmam therapy. $1^{\text {st }}$ ed. Ministry of Health, Malaysia; 2016. p. 17-9.

6. N Shanmugam, Varma Maruthuva Adipadai Kalvi. Thirumoolar Varmology Institute; 2014.

7. Stein C. The control of pain in peripheral tissue by opioids. N Engl J Med 1995;332;1685-90.
8. Miller R. Miller's Anesthesia. 6th ed. Pennsylvania: Elsevier; 2005. p. 382-6.

9. Brunton L. Goodman and Gilman's The pharmacological basis of therapeutics. $11^{\text {th }}$ ed. New York: McGraw-Hill; 2006. p. 547-59.

\section{How to cite this article}

- Meena R, Natarajan S, Anbarasi C, Muralidass SD. Effect of varmam therapy in santhu vatham (Osteo arthritis-knee joint)-a single case study. Int J Pharm Pharm Sci 2017;9(9):284-287. 